\title{
Yenilenebilir Enerji Tüketimi İle Ekonomik Büyüme Arasındaki İlişki: G-20 Ülkeleri ${ }^{1}$
}

İbrahim BAKIRTAŞ, Department of Economics, Faculty of Economics and Administrative Sciences, Aksaray University, Turkey; e-mail: ibakirtas@aksaray.edu.tr

Mümin Atalay ÇETIN, Department of Economics, Faculty of Economics and Administrative Sciences, Aksaray University, Turkey; e-mail: atalaycetin@aksaray.edu.tr

\section{The Relationship between Renewable Energy Consumption and Economic Growth: G-20 Countries²}

\begin{abstract}
The main purpose of this study is to determine the effects of an increase in real income per capita on renewable energy consumption per capita during 1992 and 2010. The panel cointegration analysis results of this study points out the existence of a long run relationship among renewable energy consumption and economic growth for G-20 countries. Afterwards the direction of this long run relationship is estimated by panel model estimators. In this regard it is found that $1 \%$ increase in real GDP per capita causes a $0,56 \%, 79 \%$ and $0,59 \%$ increase in renewable energy consumption per capita respectively for POLS, REM and FGLS analysis. According to the ECM results, renewable energy consumption per capita increases while real GDP per capita rises in the long term for approximately $33 \%$ of the sample.
\end{abstract}

Keywords

Environmental Kuznets Curve, Panel Data Analysis, G-20 Countries, Renewable Energy, Economic Growth.

JEL Classification Codes : $\quad$ Q50, Q56, Q57, Q43.

\section{$\ddot{\mathbf{O} z}$}

$\mathrm{Bu}$ çalışmanın temel amacı, 1992-2010 yıllarında, G-20 ülkeleri için kişi başına gelirde meydana gelen artışın kişi başına düşen yenilenebilir enerji tüketiminde nasıl bir değişim meydana getirdiğini ortaya koymaktır. Panel eş bütünleşme analiz sonuçları G-20 ülkelerinde yenilenebilir enerji tüketimi ile ekonomik büyüme arasında uzun dönemli bir ilişkinin var olduğunu ortaya koymuştur. Daha sonra ise elde edilen bu uzun dönemli ilişkinin yönü panel model tahmincileri yardımıyla ortaya konmuştur. Kişi başına reel GSYIHH'da meydana gelen \%1'lik artışın, kişi başına

I Bu çalışma 12-15 Mayls 2015 tarihlerinde Amsterdam'da yapılan $16^{\text {th }}$ International Academic Conference (IISES-2015)'da özet metin olarak sunulmuştur.

2 An earlier version of this paper was presented in $16^{\text {th }}$ International Academic Conference (IISES-2015) in Amsterdam on $12^{\text {th }}$ and $15^{\text {th }}$ May 2015. 
yenilebilir enerji tüketiminde; POLS analizine göre \%0.56'llk, REM analizine göre \%0.79'luk ve FGLS analizine göre \%0.59'luk bir artışa neden olduğu saptanmıştır. Diğer yandan ECM analizi örneklem grubunun yaklaşık \%33'nde ekonomik büyümenin yenilenebilir enerji tüketimini arttırdığı saptanmıştır.

Anahtar Sözcükler $\quad$ : Çevresel Kuznets Eğrisi, Panel Veri Analizi, G-20 Ülkeleri, Yenilenebilir Enerji, Ekonomik Büyüme.

\section{Giriş}

Enerji tüketimine bağlı sera gazı (karbon dioksit $\left(\mathrm{CO}_{2}\right)$, sülfür oksit $\left(\mathrm{SO}_{2}\right)$ vb.) salınımı birçok araştırmacıya göre çevre kirliliği, ozon seyrekleşmesi, iklim değişikliği ve küresel 1sınma gibi çevresel sorunların temel nedenidir (Nordhaus, 1991; Pearce, 1991; Solomon et al., 2008). Uluslararası Enerji Ajansı'nın (IEA) Dünya Enerji Görünümü (WEO)- 2014 adlı çalışmasına göre dünya genelinde $\mathrm{CO}_{2}$ emisyonu 2011 yılından beri \%1,2 oranında artmıştır ve bu artış yaklaşık olarak 400 milyon ton $\mathrm{CO}_{2}$ gazı salınımına eş değer olmaktadir.

İktisat literatüründe, Çevresel Kuznets Eğrisi (EKC) hipotezi uzun dönemde $\mathrm{CO}_{2}$ emisyonunun, kişi başına düşen gelir düzeyinde meydana gelen artışla birlikte azalacağını ileri sürmektedir. Her ne kadar bu iktisadi fenomen ilk olarak Grossman ve Krueger (1991) tarafından ileri sürülmüşse de Çevresel Kuznets Eğrisi'nin temelleri Kuznets (1955) tarafından atılmıştır. Kuznets (1955) kişi başına düşen gelir düzeyinde meydana gelen artışın, ilk aşamada gelir adaletsizliğini artıracağını ancak ekonomik büyümenin ileri safhalarında kişi başına düşen gelir düzeyinde meydana gelen artışla birlikte gelir adaletsizliğinin de azalacağını ifade etmiştir. 90’ların başında kişi başına düşen gelir düzeyi ile gelir adaletsizliği arasında uzun dönemde var olduğu ifade edilen ters U biçimindeki ilişki, çevre kirliliği ile kişi başına düşen gelir düzeyi arasında da tespit edilmiştir (Bakırtas vd., 2014). Grossman ve Krueger (1991, 1995), Shafik ve Bandyopadhyay (1992), Panayotou (1993, 1997), Shafik (1994), Selden ve Song (1995) iktisadi kalkınmanın ilk aşamalarında kişi başına düşen gelir düzeyinde meydana gelen artışın, kişi başına düşen $\mathrm{CO}_{2}$ emisyon düzeyini de arttıracağını ancak kalkınmanın ileri safhalarında gelir düzeyinde meydana gelen artışın $\mathrm{CO}_{2}$ emisyon düzeyinde azalmaya neden olacağını ileri sürmüşlerdir. $\mathrm{Bu}$ durumun temel nedeni, kalkınmanın ilk safhalarında politika yapıcıların yalnızca ekonomik çıktı düzeyine ve istihdam hedeflerine odaklanması ve mevcut fosil yakıt tüketimine dayanan endüstriyel yapının yenilenebilir enerji kaynaklarına dönüşümünün oldukça maliyetli olmasıdır. Ancak ekonomik kalkınmanın ileri safhalarında kişi başına gelir düzeyinde meydana gelen artışla birlikte bireylerin çevresel konulara ilişkin duyarlılıkları artacak ve politika yapıcılar uygulamaya sundukları yasal düzenlemeler ile çevrenin korunmasına ilişkin aktif rol üstleneceklerdir (Dinda, 2004). Bu bilgiler 1şığında Çevresel Kuznets Eğrisi hipotezinden hareket edildiğinde, kişi başına düşen gelir düzeyinde meydana gelecek olan artışın, uzun dönemde yenilenebilir enerji kaynaklarına olan talebi arttırması ve bu yolla çevre dostu enerji kaynaklarının toplam enerji tüketimi içerisindeki paylarını artması beklenecektir. 
$\mathrm{Bu}$ çalışmanın amacı, yukarıda ifade edilen görüşler temel alınarak, G-20 ülke grubuna dâhil 18 ülke için; 1992-2010 yılları arasında, kişi başına düşen yenilenebilir enerji tüketimi ile kişi başına düşen reel GSYİH arasındaki uzun dönem ilişkiyi panel veri analiz tekniklerini kullanarak incelemektir. Bu çalışmada gerçekleştirilen panel eş bütünleşme testi, G-20 ülkeleri için kişi başına düşen yenilenebilir enerji tüketimi ile kişi başına düşen reel GSYİH arasında uzun dönemli ilişkinin varlığını ortaya koymak için kullanılırken, iki değişken arasındaki uzun dönemli ilişkinin yönü panel model tahmincileri yardımıyla tespit edilecektir. Ancak bu çalışmada kullanılan model tahmincilerinden havuzlanmış en küçük kareler (POLS) ve tesadüfi etkiler (REM) modelleri, veri setlerinde yatay kesitsel bağımlılık, serisel korelasyon ve değisen varyans problemlerinin olmadığı varsayımlarına dayandırılmaktadır. Bu noktadan hareketle, bu çalışmada kullanılan panel veri setinde yukarıda ifade edilen bu üç temel sorunun varlığı; Friedman (1937) ve Pesaran (2004) tarafından ortaya atılan yatay kesitsel bağımlılık testleri, Wiggins ve Poi (2001) tarafından ortaya atılan LM panel değişen varyans testi ve Wooldridge (2002) ve Drukker (2003) tarafından ortaya atılan serisel korelasyon testi yardımıyla araştırılmıştır. Bu çalışmada paneller arası değişen varyans sorununu ortadan kaldırmak için Parks (1967) tarafından geliştirilen uygulanabilir genelleştirilmiş en küçük kareler (FGLS) modeli tahmin edilerek, kişi başına yenilenebilir enerji tüketiminde meydana gelen artışın, kişi başına düşen reel GSYİH'da meydana getireceği etki tespit edilecektir.

Bu çalışma beş bölümden meydana gelmektedir. Bu bölümler; çalışmanın önemi ve amacını ortaya koyan ilk bölüm, yenilenebilir enerji tüketimiyle kişi başına düşen gelir düzeyi arasındaki uzun dönemli ilişkiyi inceleyen çalışmalara dair genel literatür değerlendirmelerinin yapıldığı ikinci bölüm, çalışmanın metodolojisi ya da bir başka deyişle analizde kullanılan veri seti ve ekonometrik uygulama tekniği hakkında bilgilerin verildiği üçüncü bölüm, araştırmanın analiz sonuçları ve bu sonuçlara ilişkin yorumlamaların yapıldığı dördüncü bölüm ve elde edilen bulguların tartışıldığı sonuç bölümüdür.

\section{Literatür}

Çevre ekonomisi literatüründe yenilenebilir enerji tüketimi ile kişi başına düşen gelir düzeyi arasındaki uzun dönemli ilişkiyi inceleyen çok sayıda çalışma mevcuttur. Literatürdeki çalışmaların büyük bölümü yukarıdaki ifade edilen iki değişken arasındaki uzun dönemli ilişkiyi panel veri ve zaman serisi analiz tekniklerini kullanarak incelemişlerdir. Tablo 1'de yenilenebilir enerji tüketimi ile ekonomik büyüme arasındaki uzun dönemli ilişkiyi inceleyen çalışmalar özetlenmiştir. 


\section{Tablo: 1}

\section{Yenilenebilir Enerji Tüketimi İle Ekonomik Büyüme Arasındaki İlişkiyi İnceleyen Çalışmalar}

\begin{tabular}{|c|c|c|c|c|}
\hline Çalışma & Metodoloji & $\begin{array}{l}\text { Zaman } \\
\text { Aralığ }\end{array}$ & $\begin{array}{c}\text { Örneklem } \\
\text { Grubu }\end{array}$ & Sonuç \\
\hline $\begin{array}{l}\text { Chien ve } \mathrm{Hu} \\
(2008)\end{array}$ & Yapısal Eşitlik Modeli (SEM) & 2003 & $\begin{array}{l}116 \\
\text { ülke }\end{array}$ & $\begin{array}{l}\text { Yenilenebilir enerji kaynaklarının kullanımı ile sermaye bilgisi arasında doğrudan } \\
\text { bir ilişki mevcutken, GSYİH ile anlamlı ve doğrudan bir ilişki bulunamamıstır. }\end{array}$ \\
\hline $\begin{array}{l}\text { Sadorsky } \\
(2009) \mathrm{a}\end{array}$ & $\begin{array}{l}\text { Panel birim kök testleri, FMOLS ve } \\
\text { DOLS panel model tahmincileri, } \\
\text { ECM ve SUR analiz teknikleri }\end{array}$ & $\begin{array}{l}1994 \\
2003\end{array}$ & $\begin{array}{c}18 \\
\text { yükselen } \\
\text { Piyasa } \\
\text { ekonomisi }\end{array}$ & $\begin{array}{l}\text { Uzun dönemde kişi başına gelirde meydana artış yenilenebilir enerji tüketimini de } \\
\text { arttırmaktadır. }\end{array}$ \\
\hline $\begin{array}{l}\text { Sadorsky } \\
(2009) \mathrm{b}\end{array}$ & $\begin{array}{l}\text { Panel birim kök testleri, FMOLS ve } \\
\text { DOLS panel model tahmincileri, } \\
\text { ECM ve SUR analiz teknikleri }\end{array}$ & $\begin{array}{l}1980 \\
2005\end{array}$ & $\begin{array}{l}\text { G-7 } \\
\text { ülkeleri }\end{array}$ & $\begin{array}{l}\text { Uzun dönem zarfında reel GSYİH'da ve } \mathrm{CO}_{2} \text { emisyonunda meydana gelen artış } \\
\text { yenilenebilir enerji tüketimini pozitif yönde etkilerken, petrol fiyatlarındaki } \\
\text { artışların yenilenebilir enerji tüketimine negatif bir etkisi söz konusudur. }\end{array}$ \\
\hline $\begin{array}{l}\text { Apergis ve } \\
\text { Payne } \\
(2010) \mathrm{a}\end{array}$ & $\begin{array}{c}\text { Panel birim kök testleri, Panel } \\
\text { Pedroni eş bütünleşme analizi, } \\
\text { FMOLS panel model tahmincisi, } \\
\text { ECM ve Panel nedensellik } \\
\text { analizleri } \\
\end{array}$ & $\begin{array}{l}1992- \\
2007\end{array}$ & $\begin{array}{l}13 \\
\text { Avrasya } \\
\text { ülkesi }\end{array}$ & $\begin{array}{l}\text { Yenilenebilir ve yenilenemeyen enerji tüketimleri ile ekonomik büyüme arasında, } \\
\text { kısa ve uzun dönemde, karşıllklı bir Granger nedensellik tespit edilmiştir. }\end{array}$ \\
\hline $\begin{array}{l}\text { Apergis ve } \\
\text { Payne } \\
(2010) b\end{array}$ & $\begin{array}{c}\text { Panel birim kök testleri, Panel } \\
\text { Pedroni eş bütünleşme analizi, } \\
\text { FMOLS panel model tahmincisi, } \\
\text { ECM ve Panel nedensellik } \\
\text { analizleri }\end{array}$ & $\begin{array}{l}1985 \\
2005\end{array}$ & $\begin{array}{l}\text { OECD } \\
\text { ülkeleri }\end{array}$ & $\begin{array}{l}\text { Yenilenebilir enerji tüketimi ile ekonomik büyüme arasında, kısa ve uzun } \\
\text { dönemde, karşlıklı bir Granger nedensellik tespit edilmiştir. }\end{array}$ \\
\hline $\begin{array}{l}\text { Apergis et } \\
\text { al. } \\
(2010) \mathrm{c}\end{array}$ & $\begin{array}{l}\text { Panel birim kök testleri, LLL eş } \\
\text { bütünleşme analizi, ECM ve panel } \\
\text { nedensellik analizleri. }\end{array}$ & $\begin{array}{l}1984 \\
2007\end{array}$ & $\begin{array}{l}19 \text { gelişmiş } \\
\text { ve } \\
\text { gelişmekte } \\
\text { olan ülke }\end{array}$ & $\begin{array}{l}\text { Sera gazı salınımları, nükleer enerji tüketimi ve yenilenebilir enerji tüketimi ve } \\
\text { ekonomik büyüme arasında uzun dönemli bir ilişsinin varlığı ortaya konmuştur. } \\
\mathrm{CO}_{2} \text { emisyonu ile yenilenebilir enerji kaynakları tüketimi arasında uzun dönemde } \\
\text { pozitif yönlü bir iliş̧i saptanmıştır. }\end{array}$ \\
\hline $\begin{array}{l}\text { Apergis ve } \\
\text { Payne } \\
(2011) \mathrm{a}\end{array}$ & $\begin{array}{c}\text { Panel birim kök testleri, Panel } \\
\text { Pedroni eş bütünleşme analizi, } \\
\text { FMOLS panel model tahmincisi, } \\
\text { ECM ve Panel nedensellik } \\
\text { analizleri } \\
\end{array}$ & $\begin{array}{l}1980 \\
2006\end{array}$ & $\begin{array}{l}6 \text { Orta } \\
\text { Amerika } \\
\text { Ülkesi }\end{array}$ & $\begin{array}{l}\text { Yenilenebilir enerji tüketimi ile ekonomik büyüme arasında, kısa ve uzun } \\
\text { dönemde, karşlıklı bir nedensellik tespit edilmiştir. }\end{array}$ \\
\hline $\begin{array}{l}\text { Menegaki } \\
(2011)\end{array}$ & $\begin{array}{l}\text { Tek-yönlü tesadüfi etkiler modeli } \\
\text { (REM), ECM ve Panel nedensellik } \\
\text { analizleri } \\
\end{array}$ & $\begin{array}{l}1997 \\
2007\end{array}$ & $\begin{array}{l}27 \text { Avrupa } \\
\text { ülkesi }\end{array}$ & $\begin{array}{l}\text { Yenilenebilir enerji tüketimi ile ekonomik büyüme arasında kısa ve uzun dönem } \\
\text { zarfında herhangi bir nedensellik tespit edilememiştir. }\end{array}$ \\
\hline $\begin{array}{c}\text { Fang } \\
(2011) \\
\end{array}$ & OLS model tahmincisi & $\begin{array}{l}1978 \\
2008 \\
\end{array}$ & Çin & $\begin{array}{l}\text { Yenilenebilir enerji tüketimi arttıkça reel GSYİH ve kişi başı reel GSYİH'nın da } \\
\text { arttığı saptanmıştır. }\end{array}$ \\
\hline $\begin{array}{l}\text { Menyah ve } \\
\text { Wolde- } \\
\text { Rufuel } \\
(2011)\end{array}$ & Granger nedensellik analizi & $\begin{array}{l}1960 \\
2007\end{array}$ & $\mathrm{ABD}$ & $\begin{array}{l}\text { Yenilenebilir enerji tüketiminden } \mathrm{CO}_{2} \text { emisyonuna doğru herhangi bir nedensellik } \\
\text { tespit edilememiştir. }\end{array}$ \\
\hline $\begin{array}{l}\text { Apergis ve } \\
\text { Payne } \\
(2011) b\end{array}$ & $\begin{array}{c}\text { Panel birim kök testleri, Panel } \\
\text { Pedroni eş bütünleşme analizi, } \\
\text { FMOLS panel model tahmincisi, } \\
\text { ECM ve Panel nedensellik } \\
\text { analizleri } \\
\end{array}$ & $\begin{array}{l}1990 \\
2007\end{array}$ & $\begin{array}{c}25 \\
\text { Gelişmiş, } \\
55 \\
\text { Gelişmekte } \\
\text { olan ülke } \\
\end{array}$ & $\begin{array}{l}\text { Yenilenebilir ve yenilenemeyen enerji tüketimleri ile ekonomik büyüme arasında, } \\
\text { kısa ve uzun dönemde, karşıllklı bir nedensellik tespit edilmiştir. }\end{array}$ \\
\hline $\begin{array}{l}\text { Tugcu et al. } \\
\text { (2012) }\end{array}$ & $\begin{array}{l}\text { Panel birim kök testleri, ARDL eş } \\
\text { bütünleşme analizi ve Panel } \\
\text { nedensellik analizi }\end{array}$ & $\begin{array}{l}1980 \\
2009\end{array}$ & $\begin{array}{l}\text { G-7 } \\
\text { ülkeleri }\end{array}$ & $\begin{array}{l}\text { Fransa, İtalya, Kanada ve ABD için kişi başına gelir ile yenilenebilir enerji } \\
\text { tüketimi arasında herhangi bir nedensellik ilişkisi bulunamazken, İngiltere ve } \\
\text { Japonya için tek yönlü bir nedensellik, Almanya için ise bu iki değişken arasında } \\
\text { karşıllklı nedensellik saptanmıştır. }\end{array}$ \\
\hline $\begin{array}{l}\text { Apergis ve } \\
\text { Payne } \\
(2012)\end{array}$ & $\begin{array}{c}\text { Panel birim kök testleri, Panel } \\
\text { Pedroni eş bütünleşme analizi, } \\
\text { FMOLS panel model tahmincisi, } \\
\text { ECM ve Panel nedensellik } \\
\text { analizleri } \\
\end{array}$ & $\begin{array}{l}1990 \\
2007\end{array}$ & $\begin{array}{c}80 \\
\text { ülke }\end{array}$ & $\begin{array}{l}\text { Yenilenebilir ve yenilenemeyen enerji tüketimleri ile ekonomik büyüme arasında, } \\
\text { kısa ve uzun dönemde, karşıllklı bir Granger nedensellik tespit edilmiştir. }\end{array}$ \\
\hline $\begin{array}{l}\text { Ocal ve } \\
\text { Aslan } \\
(2013)\end{array}$ & $\begin{array}{c}\text { Panel birim kök testleri, ARDL eş } \\
\text { bütünleşme analizi ve Toda- } \\
\text { Yamamoto } \\
\text { nedensellik analizi }\end{array}$ & $\begin{array}{l}1990 \\
2010\end{array}$ & Türkiye & $\begin{array}{l}\text { Yenilenebilir enerji tüketiminde meydana gelen artışın ekonomik büyüme üzerinde } \\
\text { negatif yönde bir etkisi olduğu tespit edilmiştir. Diğer yandan ekonomik } \\
\text { büyümeden yenilenebilir enerji tüketimine doğru tek yönlü bir nedenselliğin varlığ1 } \\
\text { tespit edilmiştir. }\end{array}$ \\
\hline $\begin{array}{l}\text { Pao ve Fu } \\
\text { (2013) }\end{array}$ & $\begin{array}{l}\text { Zaman serisi birim kök testleri, } \\
\text { Zaman serisi eş bütünleşme analizi } \\
\text { ve ECM ve nedensellik analizleri }\end{array}$ & $\begin{array}{l}1980 \\
2010\end{array}$ & Brezilya & $\begin{array}{l}\text { Hidroelektrik olmayan yenilenebilir enerji tüketiminden (NREC) ekonomik } \\
\text { büyümeye doğru tek yönlü bir nedensellik iliş̧kisi bulunmuşken, toplam enerji } \\
\text { tüketimi (TREC) ile ekonomik büyüme arasında karşlıklı bir nedensellik tespit } \\
\text { edilmiş ve son olarak ekonomik büyümeden NREC ve TREC'e doğru tek yönlü bir } \\
\text { nedenselliğin varlığı ortaya konmuștur. }\end{array}$ \\
\hline
\end{tabular}

Tablo 1'e göre mevcut literatürde yenilenebilir enerji tüketimi ile ekonomik büyüme arasındaki uzun dönemli ilişki, G-20 ülkeleri örneklem grubu için, EKC hipotezi çerçevesinde incelenmemiştir. G-20 ülkeleri örneklem grubu dünya çapında en büyük ve 
gelişmiş 19 ekonomiyi içermesi dolayısıyla, kişi başına düşen gelir düzeyinde meydana gelecek olan artışların yenilenebilir enerji tüketiminde meydana getireceği uzun dönem etkinin net bir şekilde görülebileceği bir örneklem grubudur. Bu özelliği nedeniyle G-20 ülkeleri örneklem grubu için, panel eş bütünleşme ve panel model tahmincileri yardımıyla, uzun dönemde kişi başına düşen reel GSYİH'da meydana gelen artışların, kişi başına düşen yenilenebilir enerji tüketiminde meydana getireceği değişimler incelenecek ve çalışmanın üçüncü bölümünde panel veri seti ve ekonometrik yöntem hakkında bilgiler verilecektir.

\section{Panel Veri Seti ve Ekonometrik Yöntem}

\subsection{Panel Veri Seti}

$\mathrm{Bu}$ çalışma G-20 ülkeleri için, EKC hipotezi çerçevesinde, kişi başına reel GSYİH'da meydana gelecek olan bir artışın, kişi başına düşen yenilenebilir enerji tüketiminde uzun dönemde yol açacağı etkiyi tespit etmeyi amaçlamaktadır. Bu bağlamda G-20 ülkelerine ait kişi başına düşen reel GSYİH (2005 ABD \$ cinsinden) verisi Dünya Bankası veri setinden elde edilmiştir. Diğer yandan G-20 ülkeleri için toplam yenilenebilir elektrik enerjisi tüketimi (milyar kilowatt/saat cinsinden) verileri ABD Enerji Bakanlığı (EIA)'nın veri setinden, nüfusa (milyon kişi cinsinden) ilişkin veriler ise Dünya Bankası veri setinden derlenmiştir. Ayrıca kişi başına düşen yenilebilir elektrik enerjisi tüketimi, her bir ülke için toplam yenilenebilir elektrik enerjisi verisinin nüfus değerlerine bölünmesiyle elde edilmiştir. Bunlara ek olarak yıllık panel veri setleri 1992-2010 yılları arasını kapsamaktadır. Panel veri setine dâhil edilen tüm veriler doğal logaritma cinsinden analizlerde kullanılmıştır. Bu çalışmada, EIA 'nın veri setinden hareketle, 1992-2010 yılları arasında, Suudi Arabistan'a ait herhangi bir yenilebilir elektrik enerjisi tüketimine ulaşılamadığından ve Avrupa Konseyi analizin dışında tutulduğundan, G-20 ülke grubunda yer alan 18 ülke ekonometrik analize dâhil edilmiştir.

\subsection{Panel Veri Analizi}

Ekonometrik veri setleri zaman serisi, kesit veri ve her ikisinin birleşiminden oluşan havuzlanmış panel veri olarak üçe ayrılmaktadır. Panel veriler aynı yatay kesit birimlerinin zaman içerisindeki değişimlerini de içermektedir. Bu nedenle panel veri analizi, zaman boyutuna sahip yatay kesit veriler kullanılarak ekonomik ilişkilerin tahmin edilmesidir (Gujarati \& Porter, 2009; Wooldridge, 2002). Bir panel veri setinde her birim aynı gözlem sayısına sahipse, bu panel veri setinin dengeli panel olduğu, ancak bazı verilerin gözlem sayısında eksiklikler mevcutsa bu panel veri setinin dengesiz panel olduğu ifade edilmektedir (Matyas \& Sevestre, 2008; Wooldridge, 2002).

Genel bir panel veri modeline ilişkin matematiksel eşitlik aşağıdaki gibidir:

$$
Y_{i t}=a_{i t}+\beta_{i t} X_{i t}+u_{i t} \quad i=1, \ldots \ldots \ldots \ldots, N ; t=1, \ldots \ldots \ldots \ldots . . N
$$


Yukarıdaki eşitlikte $Y$; bağımlı değişkeni, $X_{k}$; bağımsız değişkeni, $a$; sabit katsayısını, $\beta$; eğim parametrelerini ve $u$; hata terimini ifade etmektedir. Diğer yandan $i$ alt indisi zaman dilimini (gün, ay, yıl gibi) göstermektedir (Tatoğlu, 2012). Ayrıca eşitlik 1'de yer alan $u_{i t}$ hata teriminin tüm zaman ve birimler için bağımsız ve $u_{i t} \approx \operatorname{IID}\left(0, \sigma^{2}\right)$ şeklinde dağılım gösterdiği varsayılmaktadır (Maddala, 1992).

Literatürde birçok araştırmacı panel veri modellerinin diğer analiz tekniklerine göre sahip olduğu avantajları sıralamışlardır. Bu avantajlardan ilki panel veri analizlerinde, zaman serilerinden ve kesit verilerden farklı olarak çok sayıda ülkenin analize birlikte dâhil edilebilmesidir. Diğer bir avantaj ise panel veri analizinin, zaman serisi verilerine ya da kesit verilere kıyasla karmaşık davranışsal modelleri kurmada ve test etmede daha başarılı olmasıdır. Panel veri analizine ilişkin üçüncü bir avantaj, panel verilerin saf kesit veri ya da saf zaman serisi analizlerinde tespit edilemeyen etkileri saptamak ve ölçmek konusunda daha başarılı olmasıdır. Bunlara ek olarak panel veri analizine ilişsin en önemli avantajlardan bir diğeri ise bireylere ait davranışsal değişikliklerin modellenmesinde daha fazla esneklik sunabilmesidir. Ayrıca panel veri analizi diğer analiz tekniklerinden farklı olarak bireysel heterojenliği kontrol edilebilmektedir. Diğer yandan panel veri analizlerinde dinamik düzenlemelere ilişkin daha iyi sonuçlar elde edilebilmektedir. Panel veri analizlerine ilişkin diğer bazı önemli avantajlar ise bu analiz tekniği sayesinde daha aydınlatıcı bilgi elde edilebilmesi, daha fazla olasılığa ulaşılması, değişkenler arasındaki doğrusal bağlantının azaltılması, serbestlik derecesinin artması ve daha etkin sonuçların elde edilmesi olarak gösterilebilir (Hsiao, 2003; Baltagi, 2010; Tarı, 2010; Greene, 2012).

Açıklayıcı değişkenler arasında bağımlı veya bağımsı değişkenlerin gecikmeli değerlerinin olmadığı panel veri modelleri statik modeller olarak adlandırılmaktadır. Statik panel veri analizlerinde, havuzlanmış panel veri (POLS), sabit etkiler (FE) ve tesadüfi etkiler (RE) model tahmincileri kullanılmaktadır. Havuzlanmış panel veri model tahmincisi yatay kesit verilerin homojen olduğu durumlarda tercih edilmekle birlikte, veri setinde yer alan birimlere özgü veya zamana özgü etkiler sabit olarak varsayıldığında sabit etkiler modeli yardımıyla analiz gerçekleştirilecektir. Diğer yandan birimlere veya zamana özgü etkiler modele hata teriminin bileşeni olarak dâhil edildiğinde tesadüfi etkiler model tahmincisi kullanılmaktadır (Baltagi, 2005; Gujarati \& Porter, 2009).

Bu bağlamda eşitlik 2 ve 3 sırasıyla sabit etkiler ve tesadüfi etkiler modellerinin matematiksel tanımlamalarını ortaya koymaktadır.

Sabit etkiler modeli,

$$
y_{i t}=\alpha_{i}+\sum_{k=1}^{K} \beta_{k} x_{k i t}+u_{i t} \quad i=1+\ldots . N, t=1, \ldots \ldots . . T
$$

Tesadüfi etkiler modeli, 


$$
y_{i t}=\alpha_{i}+\sum_{k=1}^{K} \beta_{k} x_{k i t}+\left(\alpha_{i}+u_{i t}\right) \quad i=1+\ldots . N, t=1, \ldots \ldots . . T
$$

biçiminde ifade edilmektedir (Arrelano, 2004; Taş et al., 2014).

$\mathrm{Bu}$ bilgilerden hareketle bölgesel etkinin veya zaman etkisinin açıklayıcı değişkenler ile ilişkili olup olmamasına bağlı olarak FE veya RE model tahmincilerinden hangisinin tercih edileceğine Hausman (1978) tarafından geliştirilmiş olan spesifikasyon testi yardımıyla karar verilmektedir. Bu bağlamda Hausman test istatistiğine göre, modeldeki bağımsız değişkenler ile gözlemlenemeyen grup etkileri arasında bir korelasyon yoksa RE model tahmincisinin daha tutarlı sonuçlar vermesi beklenecektir. Diğer yandan statik panel veri model tahminlerine geçmeden önce, mevcut panel veri setinde, parametrelerde etkinlik kaybına ve standart hataların yanlış tahmin edilmesine neden olabilecek üç temel sorun vardır. Bu sorunlar, panel veri setinde serisel korelasyonun, değişen varyansın ve yatay kesitsel bağımlılığın var olmasıdır. Bu bağlamda panel veri setinde serisel korelasyon sorunu Wooldridge (2002) ve Drukker (2003) tarafindan geliştirilen serisel korelasyon testi yardımıyla araştırılmaktadır. Bu test sonucunda elde edilen test istatistiğine ait olasılık değerinin $\% 5$ 'ten büyük olması durumunda $\mathrm{H}_{0}$ hipotezi red edilemez ve panel veri setinde serisel korelasyonun olmadiğ ifade edilecektir. Diğer yandan panel veri setinde değişen varyans sorunun varlığı Wiggins ve Poi (2001) tarafindan ortaya konan değişen varyans testi ile incelendiğinde, test istatistiğine ait olasıllk değeri $\% 5$ 'ten büyükse $\mathrm{H}_{0}$ hipotezi red edilemez ve mevcut panel veri setinde değişen varyans sorunun olmadığ ifade edilir. Son olarak panel veri setinde yatay kesit bağımlılığ 1 sorunun olup olmadığı Friedman (1937) ve Pesaran (2004) tarafindan geliştirilen testler yardımıyla incelendiğinde, ulaşılan test istatistiklerine ait olasılık değerleri \%5'ten büyükse $\mathrm{H}_{0}$ hipotezi red edilemez ve panel veri setinde yatay kesitsel bağımlılık sorunun olmadığı ifade edilir. Bu bağlamda literatürde panel veri modelinde bu sorunlardan birinin veya birkaçının varlığ tespit edildiğinde, bu sorunların ortadan kaldırılması ve daha sağlıklı sonuçların elde edilebilmesi için Parks (1967) tarafindan geliştirilen uygun genelleştirilmiş en küçük kareler (FGLS) veya Beck ve Katz (1995) tarafindan ortaya atılan standart hataları düzeltilmiş panel (PCSE) yöntemleri kullanılmaktadır.

\section{Ampirik Bulgular ve Değerlendirme}

EKC hipotezinden hareketle, kişi başına düşen yenilebilir enerji tüketimi ile kişi başına düşen reel GSYİH arasındaki uzun dönemli ilişki incelenmeden önce, bu iki veri setinde panel birim kökün varlığı araştırılacaktır. Ancak kişi başına düşen yenilenebilir enerji tüketimi ile kişi başına düşen reel GSYİH verileri için panel birim kök testleri araştırılmadan önce, panel veri setinde yatay kesitler arasındaki bağımlılık, Friedman (1937) ve Pesaran (2004) yatay kesit bağımlılık testleri yardımıyla incelenmiştir. Tablo 4'de görüleceği üzere panel veri setinde yatay kesit bağımlılığına rastlanmamıştır. Panel veri setinde birimler arasında yatay kesit bağımlılığı tespit edilemediği için kişi başına düşen 
yenilenebilir enerji tüketimi ile kişi başına düşen reel GSYİH verilerinde birim kökün varlığ1 birinci nesil birim kök testleri yardımıyla araştırılmıştır.

Çalışmada kullanılan panel veri seti dengesiz (unbalanced) panel olduğu için, yukarıda ifade edilen iki değişken için durağanlık Im et al. (2003) tarafından ileri sürülen IPS ve Choi (2001) tarafindan geliştirilen Fisher ADF ve Fisher PP birim kök testleri yardımıyla incelenmiştir. Bu bağlamda, çalışmaya dâhil edilen 18 ülke için, kişi başına düşen yenilenebilir enerji tüketimi ile kişi başına düşen reel GSYİH verilerine ilişkin panel birim kök test sonuçları, serilerin birinci dereceden farklarının durağan olduğunu ortaya çıkarmıştır. Panel birim kök testlerine ilişkin sonuçlar Tablo 2'de özetlenmiş olup, Tablo 2'in ikinci sütununda IPS test istatistiğine ait sonuçlar, üçüncü ve dördüncü sütunda ise Fisher ADF ve Fisher PP test istatistiklerine ait sonuçlar ortaya konmuş ve parantez içerisinde olasılık değerleri verilmiştir.

Tablo 2'de kişi başına düşen yenilenebilir enerji tüketimi (lnRen) ve kişi başına düşen reel GSYİH (lnY) verilerine ilişkin birim kök testleri hesaplanırken, optimum gecikme uzunluğu AIC bilgi kriterine göre belirlenmiştir. Bu bağlamda lnRen verisi düzeyde ve üçüncü gecikmede IPS ve Fisher ADF test sonuçlarına göre durağan değilken, Fisher PP testinde $\% 5$ anlamlılık düzeyinde durağan bulunmuştur. Diğer yandan $\ln Y$ verisi düzeyde ve üçüncü gecikmede IPS, Fisher ADF ve Fisher PP testi için durağan bulunmamıştır.

Tablo: 2

Panel Birim Kök Test Sonuçları (Düzeyde ve 3. Dereceden Gecikme)

\begin{tabular}{|c|c|c|c|c|c|c|}
\hline & \multicolumn{2}{|c|}{ IPS } & \multicolumn{2}{|c|}{$\overline{~ F i s h e r ~ A D F ~}$} & \multicolumn{2}{|c|}{ Fisher PP } \\
\hline & InRen & $\ln Y$ & InRen & $\ln \mathbf{\operatorname { l n } Y}$ & 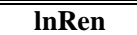 & $\ln Y$ \\
\hline G-20 & -0.7117 & 5.4062 & 29.0275 & 19.5231 & $54.7194 * *$ & 17.3929 \\
\hline ülkeleri & $(0.2383)$ & $(1.0000)$ & $(0.7886)$ & $(0.9885)$ & $(0.0236)$ & $(0.9962)$ \\
\hline
\end{tabular}

Not: ${ }^{*}, * *, * * *$ ifadeleri sirastyla istatistiksel olarak \%10,\%5 ve\%1 anlamlıllk düzeylerini göstermektedir. Olasılık değerleri ise parantez içerisinde verilmiştir.

Birim kök test sonuçlarından hareketle kişi başına düşen yenilenebilir enerji tüketimi ve kişi başına düşen reel GSYIHH verilerinin düzeyde ve üçüncü gecikmede durağan olmadıkları tespit edildikten sonra, bu iki değişken arasındaki uzun dönemli ilişkinin varlığı Pedroni (1999) tarafından geliştirilen panel eş bütünleşme testi yardımıyla incelenmiştir. Bu bağlamda Tablo 3, analizde yer alan 18 ülkenin $\operatorname{lnRen}$ ve $\ln Y$ verileri için Pedroni panel eş bütünleşme test sonuçlarını göstermektedir. 
Tablo: 3

\section{Pedroni Panel Eş Bütünleşme Test Sonuçları}

\begin{tabular}{|c|c|c|c|c|c|c|c|}
\hline & \multicolumn{7}{|c|}{ Pedroni Panel Eș Bütünleșme Test İstatistikleri } \\
\hline & Panel-v & Panel-rho & $\begin{array}{c}\text { Panel } \\
\text { PP }\end{array}$ & $\begin{array}{c}\text { Panel } \\
\text { ADF }\end{array}$ & Group -rho & $\begin{array}{c}\text { Group } \\
\text { PP }\end{array}$ & $\begin{array}{c}\text { Group } \\
\text { ADF }\end{array}$ \\
\hline $\begin{array}{c}\text { G-20 } \\
\text { ülkeleri }\end{array}$ & $\begin{array}{l}1.5833 * \\
(0.0567) \\
\end{array}$ & $\begin{array}{c}-6.2594 * * * \\
(0.0000)\end{array}$ & $\begin{array}{c}-7.1596 * * * \\
(0.0000)\end{array}$ & $\begin{array}{c}-7.3478 * * * \\
(0.0000)\end{array}$ & $\begin{array}{c}-2.1591 * * \\
(0.0154)\end{array}$ & $\begin{array}{c}-4.7082 * * * \\
(0.0000)\end{array}$ & $\begin{array}{c}-5.6776^{* * * *} \\
(0.0000)\end{array}$ \\
\hline
\end{tabular}

Not:*, **, *** ifadeleri sirastyla istatistiksel olarak \%10, \%5 ve \%1 anlamlilık düzeylerini göstermektedir. Olasillk değerleri ise parantez içerisinde verilmişstir.

Tablo 3'den de görülebileceği üzere, Pedroni panel eş bütünleşme analizine ait yedi test istatistiğinin yedisi de istatistiksel olarak anlamlı bulunmuştur. Bu bağlamda Pedroni panel eş bütünleşme test istatistiklerinden Panel-rho, Panel PP, Panel ADF, Group PP ve Group ADF test istatistikleri \%1 anlamlılık düzeyinde, Group-rho test istatistiği $\% 5$ anlamlılık düzeyinde ve Panel-v test istatistiği $\% 10$ anlamlılık düzeyinde anlamlı bulunmuştur. Bu durumda Tablo 2'de ifade edilen Pedroni panel eş bütünleşme sonuçları $\operatorname{lnRen}$ ve $\operatorname{lnY}$ verileri arasında uzun dönemli bir ilişkinin varlığını ortaya koymaktadır.

Bu çalışmada Pedroni panel eş bütünleşme analizi gerçekleştirildikten sonra, kişi başına düşen reel GSYIHH'da meydana gelen artışın kişi başına düşen yenilenebilir enerji tüketimini nasıl etkileyeceğini açıklamak için panel veri model tahmincilerinden havuzlanmış en küçük kareler (POLS) tahmincisi ve literatürde çokça tercih edilen iki statik doğrusal panel veri analiz tekniği olan sabit etkiler (FE) veya tesadüfi etkiler (RE) model tahmincileri kullanılacaktır. Daha önce de ifade edildiği üzere bölgesel etkinin açıklayıcı değişkenler ile ilişkili olup olmamasına bağlı olarak FE veya RE model tahmincilerinden hangisinin tercih edileceğine Hausman (1978) tarafindan geliştirilmiş olan spesifikasyon testi yardımıyla karar verilmektedir. Tablo 4 'te görüleceği üzere Hausman test istatistiğine ait olasılık değerinin 0.27 olduğu tespit edilmiş ve böylece $\mathrm{H}_{0}$ hipotezi red edilmemiş ve bu çalışmada RE model tahmincisi tercih edilmiştir. Ancak hem POLS hem de RE model tahmincileri serilerde yatay kesit bağımlılığ probleminin olmadığ 1 temel varsayımına dayanmaktadır (Nargeleçekenler, 2011). Bu noktadan hareketle bu çalışmada panel veri model tahminlerine geçmeden önce, mevcut panel veri setinde, parametrelerde etkinlik kaybına ve standart hataların yanlış tahmin edilmesine neden olabilecek bu üç temel sorun araştırılmıştır. Bu sorunlardan ilki serisel korelasyon problemidir. Tablo 4 'te görüleceği üzere Wooldridge (2002) ve Drukker (2003) serisel korelasyon test sonucu veri setinde serisel korelasyon probleminin olmadığını ifade etmektedir. Diğer yandan panel veri setinde karşılaşılması muhtemel bir diğer sorun olan yatay kesit bağımlılığı, daha önce de ifade edildiği gibi, Friedman (1937) ve Pesaran (2004) yatay kesit bağımlılık testleri ile sınanmış ve veri setinde yatay kesit bağımlılığı olmadığ tespit edilmiştir. Buna ek olarak panel veri setinde karşılaşılması muhtemel üçüncü bir sorun ise değişen varyans sorunudur. Tablo 4'te ifade edildiği üzere, panel veri setinde değişen varyans sorunu Wiggins ve Poi (2001) tarafindan ortaya konan Lagrange çarpanı (LM) test istatiği yardımıyla test edilmiş ve veri setinde değisşen varyans probleminin olduğu tespit edilmiştir. $\mathrm{Bu}$ noktadan hareketle bu çalışmada ilk olarak değişen varyans ve ardışık 
korelasyon sorununa karşı dirençli RE (Robust) model tahmincisi kullanılmıştır. Daha sonra ise serisel korelasyon, değişen varyans ve yatay kesit bağımlılıklarına ilişkin test sonuçlarından hareketle, Parks (1967) tarafından geliştirilen değişen varyans sorununa dirençli uygulanabilir genelleştirilmiş en küçük kareler (FGLS (hetero)) yöntemi kullanılarak panel regresyon modeli tahmin edilmiştir.

Tablo: 4

\section{Panel Model Tahminleri (Bağımlı Değişken: Kişi Başına Düşen Yenilenebilir Enerji Tüketimi-Lnren)}

\begin{tabular}{lcccc}
\hline \hline & & & G-20 ülkeleri & \\
\hline \hline & Pooled OLS & RE & RE (Robust) & FGLS (hetero) \\
$\operatorname{lnY}$ & $0.56^{* * *}$ & $0.79^{* * *}$ & $0.79^{* * *}$ & $0.59^{* * *}$ \\
$\mathbf{R}^{2}$ & $(11.28)$ & $(11.04)$ & $(5.83)$ & $(58.16)$ \\
\hline \hline
\end{tabular}

F-test istatistiğ $\mathbf{i}=127.34$

Pesaran yatay kesit bağımlılı testi $=-0.630,[1.47]$

Friedman yatay kesit bağımlılık testi $=6.44$ [0.99]

Hausman test m-istatistiğ $\mathbf{i}=1.21$, [0.27]

LM değişen varyans test istatistiğ $\mathbf{i}=558.82 * * *$ [0.000]

Wooldridge serisel korelasyon test istatistiğ $i=1.241,[0.28]$

Not:*, **, *** ifadeleri slraslyla istatistiksel olarak \%10, \%5 ve \%1 anlamlllık düzeylerini göstermektedir. $t$ istatistik değerleri yuvarlak parantez, olasılık değerleri ise köşeli parantez içerisinde verilmiştir.

Tablo 4 panel model tahminlerine ilişkin sonuçları göstermektedir. Tablo 4 'teki sonuçlardan hareket edildiğinde POLS analizine göre kişi başına düşen reel GSIYH'da meydana gelen \%1'lik bir artış, kişi başına düşen yenilenebilir enerji tüketiminde \%0.56'lık bir artışa neden olmaktadır. Diğer yandan RE ve RE (Robust) analizlerine göre kişi başına düşen reel GSIYH'da meydana gelen \%1'lik bir artış, kişi başına düşen yenilenebilir enerji tüketiminde \%0.79'luk bir artışa neden olmaktadır. Son olarak FGLS (hetero) analiz sonuçları ise kişi başına düşen reel GSIYH'da meydana gelen \%1'lik bir artışın, kişi başına düşen yenilenebilir enerji tüketiminde \%0.59'luk bir artışa neden olacağını ortaya koymaktadır. Elde edilen bu sonuçlar, analizde yer alan G-20 örneklem grubuna dâhil 18 ülkede, EKC hipotezi ile uyumlu olarak, uzun dönemde kişi başına düşen reel GSYIH'da meydana gelen artışların yenilenebilir enerji tüketimini arttıracağını göstermektedir.

$\mathrm{Bu}$ çalışmada panel model tahmincilerine ilişkin bulgular değerlendirildikten sonra analize dâhil edilen 18 ülkenin her birine ait uzun dönem gelir esneklikleri hata terimi modeli (ECM) kullanılarak hesaplanmıştır. Bu bağlamda Tablo 5, G-20 ülkeleri örneklem grubunda yer alan 18 ülkenin her birine ait uzun ve kısa dönem yenilenebilir enerji tüketiminin gelir esneklik ve hata terimi sonuçlarını göstermektedir. 
Tablo: 5

Ülkeler İçin Uzun ve Kısa Dönemde Yenilenebilir Enerji Tüketiminin Gelir Esnekliği

\begin{tabular}{|c|c|c|c|c|c|c|}
\hline Ülkeler & \multicolumn{2}{|c|}{$\begin{array}{c}\text { Uzun dönem } \\
\ln Y \\
\end{array}$} & \multicolumn{2}{|c|}{$\begin{array}{c}\text { Kısa Dönem } \\
\text { InY'deki değişim } \\
\end{array}$} & \multicolumn{2}{|c|}{ Hata Düzeltme Terimi (ECT) } \\
\hline \multicolumn{7}{|l|}{ G-20 ülkeleri } \\
\hline Arjantin & 0.1661 & $(0.11)$ & 0.0411 & $(0.05)$ & $-0.4663^{*}$ & $(-1.80)$ \\
\hline Avustralya & 0.0945 & $(0.68)$ & -0.2448 & $(-0.18)$ & $-0.8210 * * *$ & $(-2.68)$ \\
\hline Brezilya & $1.2188^{* * *}$ & $(8.08)$ & -0.2585 & $(-0.53)$ & $-0.7199 * * *$ & $(-2.87)$ \\
\hline Kanada & -0.1269 & $(-1.49)$ & 0.0232 & $(0.05)$ & $-0.9196^{* * *}$ & $(-3.30)$ \\
\hline Çin & $1.0503 * * *$ & $(8.67)$ & 1.1767 & $(1.24)$ & -0.3984 & $(-1.55)$ \\
\hline Fransa & -0.4419 & $(-0.97)$ & 1.0886 & $(0.74)$ & $-0.6797 * *$ & $(-2.33)$ \\
\hline Almanya & $7.9160 * * *$ & $(5.05)$ & 0.2386 & $(0.24)$ & -0.2013 & $(-1.56)$ \\
\hline Hindistan & $0.4526^{* *}$ & $(1.96)$ & $2.3001 * *$ & $(2.21)$ & $-0.3681 * *$ & $(-2.20)$ \\
\hline Endonezya & 2.7931 & $(1.00)$ & $-1.8857 * * *$ & $(-2.51)$ & -0.1695 & $(-0.77)$ \\
\hline İtalya & 0.9142 & $(0.43)$ & -1.8872 & $(-1.48)$ & -0.2040 & $(-0.79)$ \\
\hline Japonya & $0.8648 * *$ & $(2.04)$ & -0.0870 & $(-0.09)$ & $-1.1111^{* * *}$ & $(-4.14)$ \\
\hline Güney Kore & $0.5320 * *$ & $(2.32)$ & -1.6405 & $(-1.19)$ & $-0.8728 * * *$ & $(-2.92)$ \\
\hline Meksika & 0.0327 & $(0.06)$ & 0.3424 & $(0.35)$ & -0.9497 *** & $(-3.44)$ \\
\hline Rusya & $0.1788^{*} * *$ & $(3.70)$ & -0.1354 & $(-0.79)$ & $-0.9788^{* * *} *$ & $(-3.66)$ \\
\hline Güney Afrika & 1.7436 & $(0.78)$ & 5.1795 & $(0.56)$ & $-0.8706^{* * *}$ & $(-3.32)$ \\
\hline Türkiye & -3.6800 & $(0.00)$ & $2.0293 * * *$ & $(3.17)$ & $-0.6626^{* * *}$ & $(-3.32)$ \\
\hline Birleşik Krallık & $3.7747 * * *$ & $(7.41)$ & $-2.6489 *$ & $(-1.70)$ & $-0.4520^{* * *}$ & $(-2.72)$ \\
\hline $\mathrm{ABD}$ & -0.6668 & $(-1.25)$ & -0.5233 & $(-0.38)$ & $-0.4699 * *$ & $(-1.94)$ \\
\hline
\end{tabular}

Not:*, **, *** ifadeleri sırasıla istatistiksel olarak \%10, \%5 ve \%1 anlamlllk düzeylerini göstermektedir. $t$ istatistik değerleri ise parantez içerisinde verilmiştir.

Tablo 5'te ifade edilen bulgular Brezilya, Hindistan, Japonya, Güney Kore, Rusya ve Birleşik Krallık için uzun dönemde kişi başına düşen reel GSiYH'da meydana gelen bir artışın, kişi başına düşen yenilenebilir enerji tüketimini arttıracağını ortaya koymuştur. $\mathrm{Bu}$ bağlamda uzun dönemde kişi başına düşen reel GSYIHH'da meydana gelecek olan \%1'lik bir artış, kişi başına düşen yenilenebilir enerji tüketiminde Brezilya'da \%1.22; Hindistan'da $\% 0.45$; Japonya'da \%0.86; Güney Kore'de \%0.53; Rusya'da \%0.18 ve Birleşik Krallık'ta \%3.77'lik bir artışa neden olacaktır. Diğer yandan uzun dönemde, kişi başına düşen reel GSYIH'da meydana gelecek olan bir artışın, Arjantin, Avusturya, Kanada, Fransa, Endonezya, İtalya, Meksika, Güney Afrika, Türkiye ve ABD’nin kişi başına düşen yenilenebilir enerji tüketimine istatistiksel olarak anlamlı bir etkisinin olmadığ 1 tespit edilmiştir. Bunlara ek olarak, her ne kadar Çin ve Almanya'nın uzun dönem gelir esneklik sonuçları istatistiksel olarak anlamlı bulunmuş olsa da, her iki ülkenin de hata terimi katsayısı istatistiksel olarak anlamsız olduğundan, bu iki ülke için uzun dönemde kişi başına düssen reel GSYİH'da meydana gelecek olan bir artışın yenilenebilir enerji tüketimini etkilediğine dair bir sonuç elde edilememiştir. Bu bağlamda ülkelere ilişkin uzun ve kısa dönemde yenilenebilir enerji tüketiminin gelir esnekliği sonuçlarından hareketle, örneklem grubunun yaklaşı \%33'ünde, EKC hipoteziyle uyumlu olarak, uzun dönemde kişi başına düşen gelir düzeyinde meydana gelecek olan artışların yenilenebilir enerji tüketimini de arttıracağı sonucuna ulaşılmıştır. 


\section{Sonuç}

Kuznets (1955)’e göre uzun dönemde ekonomik büyüme ile gelir adaleti arasında ters U biçiminde bir ilişki vardır. Bu hipotezden hareketle Grossman ve Krueger (1991) bu tip bir ilişkinin ekonomik büyüme ile çevre kirliliği arasında da olduğunu ileri sürmüştür. Çevresel Kuznets Eğrisi (EKC) hipotezi olarak adlandırılan bu iktisadi fenomene ilişkin literatür, ekonomik kalkınmanın ilk safhalarında bireylerin çevre kirliliğine ilişkin duyarlılığının az oluşu ve mevcut fosil yakıt temelli sanayi yapısının yenilenebilir enerji kaynaklarına dönüşümünün maliyetli olması nedeniyle, kişi başına düşen gelir düzeyinde meydana gelen artışların çevre kirliliğini de arttıracağını ifade etmektedir. Diğer yandan ekonomik kalkınmanın ileri safhalarında bireylerin çevrenin korunmasına ilişkin duyarlılığının artması ve buna ilişkin yasal düzenlemelerin de çoğalmasıyla, kişi başına düşen gelir düzeyinde meydana gelen artışların çevre kirliliğinde azalmaya neden olacağı beklenmektedir. Buna ek olarak ekonomik kalkınmanın ileri safhalarında, kişi başına gelir düzeyinde meydana gelen artışların yenilenebilir enerji tüketiminde artışa neden olması beklenmektedir.

Bu çalışmada, 1992-2010 yılları arasında, G-20 ülke grubuna dâhil 18 ülke için kişi başına düşen reel GSYİH ile kişi başına düşen yenilenebilir elektrik enerjisi tüketimi arasındaki uzun dönemli ilişkinin varlığ araştırma gerçekleştirilirken panel veri analiz teknikleri kullanılmıştır. Pedroni panel eş bütünleşme test sonuçları, kişi başına düşen yenilenebilir enerji tüketimi ile kişi başına düşen reel GSYİH arasında uzun dönemli bir ilişkinin varlığına işaret etmektedir. Bu ilişkinin yönünü tespit edebilmek amacıyla panel model tahmincileri de test edilmiştir. Bu bağlamda G-20 ülkeleri için kişi başına düşen reel GSYİH'da meydana gelecek olan \%1'lik bir artışın, kişi başına düşen yenilebilir enerji tüketiminde \%0.59'luk bir artışa neden olacağı tespit edilmiştir. Bu bulgular EKC hipotezi ile uyumludur. Diğer yandan bu çalışmada uzun dönemde ekonomik büyüme ile yenilenebilir enerji tüketimi arasındaki ilişki, hata terimi modeli (ECM) yardımıyla, her bir ülke için tek tek test edilmiştir. Ülkeler için gerçekleştirilen test sonuçları uzun dönemde kişi başına düşen reel GSYİH'da meydana gelecek olan artışların; Brezilya'da, Hindistan'da, Japonya'da, Güney Kore'de, Rusya'da ve Birleşik Krallık'ta kişi başına düşen yenilenebilir enerji tüketimini arttıracağını ortaya koymuştur. Bu bağlamda örneklem grubunun yaklaşık \%33'ünün, EKC hipotezi ile uyumlu sonuçlar verdiği tespit edilmiştir.

\section{Kaynaklar}

Apergis, N. \& J.E. Payne (2010a), "Renewable Energy Consumption and Growth in Eurasia", Energy Economics, 32, 1392-1397.

Apergis, N. \& J.E. Payne (2010b), "Renewable Energy Consumption and Economic Growth: Evidence from a Panel of OECD Countries", Energy Policy, 38(1), 656-660.

Apergis, N. \& J.E. Payne (2010c), "On the Causal Dynamics between Emissions, Nuclear Energy, Renewable Energy and Economic Growth”, Ecological Economics, 69, 2255-2260. 
Apergis, N. \& J.E. Payne (2011a), "The Renewable Energy Consumption-Growth Nexus in Central America", Applied Energy, 88(1), 343-347.

Apergis, N. \& J.E. Payne (2011b), "On the Causal Dynamics between Renewable and Nonrenewable Energy Consumption and Economic Growth in Developed and Developing Countries", Energy Syst., 2, 299-312.

Apergis, N. \& J.E. Payne (2012), "Renewable and Non-renewable Energy Consumption-Growth Nexus: Evidence from a Panel Error Correction Model”, Energy Economics, 34, 733738.

Arrelano, M. (2004), Panel Data Econometrics (Advanced Tests in Econometrics), New York, Oxford University Press, Inc.

Bakırtas, I. \& S. Bayrak \& A. Cetin (2014), "Economic Growth and Carbon Emission: A Dynamic Panel Data Analysis", European Journal of Sustainable Development, 3 (4), 91-102.

Baltagi, B.H. (2005), Econometric Analysis of Panel Data, 3rd Ed., Chichester: John Wiley \& Sons, Ltd.

Beck, N. \& J.N. Katz (1995), "What to do (and not to do) with Time Series Cross Section Data", The American Political Science Review, 89(3), 634-647.

Chien, T. \& J. Hu (2008), “Renewable energy: An Efficient Mechanism to Improve GDP”, Energy Policy, 36, 3045-3052.

Choi, I. (2001), "Unit Root Tests for Panel Data”, Journal of International Money and Finance, 20, 249-272.

Dinda, S. (2004), "Environmental Kuznets Curve Hypothesis: A Survey”, Ecological Economics, 49, 431-455.

Drukker, D.M. (2003), “Testing for Serial Correlation in Linear Panel-data Models", The Stata Journal, 3(2), 168-177.

Energy Information Administration of USA (2015), Renewable and Alernative Fuels, <http://www.eia.gov/todayinenergy/index.cfm?tg=renewable>, 01.03.2015.

Fang, Y. (2011), "Economic Welfare Impacts from Renewable Energy Consumption: The China Experience", Renewable and Sustainable Energy Reviews, 15(9), 5120-5128.

Friedman, M. (1937), "The Use of Ranks to Avoid the Assumptions of Normality Implicit in the Analysis of Variance", Journal of the American Statistical Association, 32(200), 675701.

Greene, W.H. (2012), Econometric Analysis, 7th Ed., New York: Prentice Hall.

Grossman, G. \& A.B. Krueger (1991), "Environmental Impacts of a North American Free Trade Agreement", NBER Working Paper, 3914, National Bureau of Economic Research, Cambridge, Mass.

Grossman, G. \& A.B. Krueger (1995), "Economic Growth and the Environment", Quarterly Journal of Economics, 112, 353-377.

Gujarati, D.N \& D.C. Porter (2009), Basic Econometrics, $5^{\text {th }}$ Ed., New York: McGraw-Hill Book Co. Hsiao, C. (2003), Analysis of Panel Data, 2nd Ed., New York: Cambridge University Press.

Hausman, J.A. (1978), "Specification Tests in Econometrics", Econometrica, 46(6), 1251-1271.

Im, K.S. \& M.H. Pesaran \& Y. Shin (2003), "Testing for Unit Roots in Heterogeneous Panels", Journal of Econometrics, 115, 53-74. 
International Energy Agency (2014), World Energy Outlook (WEO)-2014, <http://www.worldenergyoutlook.org/publications/weo-2014/>, 22.03.2015.

Kuznets, S. (1955), "Economic Growth and Economic Inequality", The American Economic Review, $45,1-28$.

Maddala, G.S. (1992), Introduction to Econometrics, $2^{\text {nd }}$ Ed., New York, Macmillan Publishing Company.

Maddala G.S. \& S. Wu (1999), “A Comparative Study of Unit Root Tests with Panel Data and a New Simple Test", Oxford Bulletin of Economics and Statistics, 61(S1), 631-652.

Matyas, L. \& P. Sevestre (2008), The Econometrics of Panel Data, Fundamentals and Recent Developments in Theory and Practice, $3^{\text {rd }}$ Ed., Verlag Berlin Heidelberg: Springer.

Menegaki, A.N. (2011), "Growth and renewable energy in Europe: A Random Effect Model with Evidence for Neutrality Hypothesis", Energy Economics, 33, 257-263.

Menyah, K. \& Y. Wolde-Rufael (2011), “ $\mathrm{CO}_{2}$ Emissions, Nuclear Energy, Renewable Energy and Economic Growth in the US", Energy Policy, 38, 2911-2915.

Nargeleçekenler, M. (2011), "Hisse Senedi Fiyatları ve Fiyat/Kazanç Oranı İlişkisi: Panel Verilerle Sektörel Bir Analiz", Business and Economics Research Journal, 2(2): 165-184.

Nordhaus, D.W. (1991), "The Cost of Slowing Climate Change: a Survey”, The Energy Journal, 12(1), 37-65.

Ocal, O. \& A. Aslan (2013), "Renewable Energy Consumption-Economic Growth Nexus in Turkey", Renewable and Sustainable Energy Reviews, 28, 494-499.

Panayotou, T. (1993), "Empirical Tests and Policy Analysis of Environmental Degradation at Different Stages of Economic Development", Working Paper, WP238, Technology and Employment Programme, Geneva, International Labor Office.

Panayotou, T. (1997), "Demystifying the Environmental Kuznets Curve: Turning a Black Box into a Policy Tool", Environment and Development Economics, 2, 465-484.

Pao, H. \& H. Fu (2013), "Renewable Energy, Non-renewable Energy and Economic Growth in Brazil", Renewable and Sustainable Energy Reviews, 25, 381-392.

Parks, R.W. (1967), "Efficient Estimation of a System of Regression Equations when Disturbances are Both Serially and Contemporaneously Correlated", Journal of the American Statistical Association, 62(318), 500-509.

Pearce, D. (1991), "The Role of Carbon Taxes in Adjusting to Global Warming”, The Economic Jounal, 101(407), 938-948.

Pedroni, P. (1999), "Critical Values for Cointegration Tests in Heterogeneous Panels with Multiple Regressors", Oxford Bulletin of Economics and Statistics, Special Issue, 0305-9049.

Pesaran, M.H. (2004), "General Diagnostic Tests for Cross Section Dependence in Panels", CESIfo Working Paper, 1229, Munich Society for the Promotion of Economic Research, Munich, Germany.

Sadorsky, P. (2009a), "Renewable Energy Consumption and Income in Emerging Economies", Energy Policy, 37(10), 4021-4028.

Sadorsky, P. (2009b), "Renewable Energy Consumption, $\mathrm{CO}_{2}$ Emissions and Oil prices in the G7 Countries", Energy Economics, 31(3), 456-462.

Shafik, N. \& S. Bandyopadhyay (1992), "Economic Growth and Environmental Quality: Time Series and Cross-Country Evidence", Background Paper for the World Development Report 1992, The World Bank, Washington DC. 
Shafik, N. (1994), "Economic Development and Environmental Quality: An Econometric Analysis", Oxford Economic Papers, 46, 757-773.

Selden, S.M. \& D. Song (1995), "Neoclassical Growth, the J curve for Abatement, and the Inverted U Curve for Pollution", Journal of Environmental Economics and Management, 29, 162168.

Solomon, S. \& G. Plattner \& R. Knutti \& P. Friedlingstein (2009), "Irreversible Climate Change due to Carbon Dioxide Emissions", PNAS, 106(6), 1704-1709.

Tarı, R. (2010), Ekonometri, İstanbul: UmuttepelEğitim Dizisi.

Taş, N. \& A. Doğan \& E. Önder (2014), “İşsizlik, Takibe Düşen Kredi ve Boşanma Oranı Değişkenlerinin Suç Sayısı Üzerine Etkisinin Belirlenmesi: Türkiye İçin Bölgesel Panel Veri Analizi”, Niğde Universitesi İ.I.B.F Dergisi, 7(1), 13-35.

Tatoğlu, F.Y. (2012), Panel Veri Ekonometrisi (Stata Uygulamalı), İstanbul: Beta Yayınları.

Tuğcu, C.T. \& I. Ozturk \& A. Aslan (2012), "Renewable and Non-renewable Energy Consumption and Economic Growth Relationship Revisited: Evidence from G7 Countries”, Energy Economics, 34, 1942-1950.

Wiggins, V. \& B. Poi, (2001), Testing for Panel-level Heteroskedasticity and Autocorrelation <http://www.stata.com/support/faqs/stat/panel.html>, 15.04.2015.

Wooldridge, J.M. (2002), Econometric Analysis of Cross Section and Panel Data, Cambridge, MA: MIT Press.

World Bank (2015), Data Indicators, <http://data.worldbank.org/indicator>, 01.03.2015. 
Bakırtaş, İ. \& M.A. Çetin (2016), "Yenilenebilir Enerji Tüketimi İle Ekonomik Büyüme Arasındaki İlişki: G-20 Ülkeleri”, Sosyoekonomi, Vol. 24(28), 131-145. 